RASĀYAN J. Chem.

Vol. 13 | No. 3 |1926-1932| July - September | 2020 ISSN: 0974-1496 | e-ISSN: 0976-0083 | CODEN: RJCABP

RJC http://www.rasayanjournal.com http://www.rasayanjournal.co.in

\title{
ANTIBACTERIAL STUDIES OF NEWLY SYNTHESIZED 3d MACROCYCLES
}

\author{
S. Sharma ${ }^{1}$, R. Mehani ne'e Chopra ${ }^{2}$ and V. Chugh, ${ }^{3, *}$ \\ ${ }^{1}$ Department of Applied Sciences, Shaheed Bhagat Singh State Technical Campus, \\ Ferozepur- 152001(Punjab), India. \\ ${ }^{2}$ Department of Chemistry, Ramgarhia Girls College Miller Ganj, \\ Ludhiana-141001(Punjab), India \\ ${ }^{3}$ Department of Chemistry, Punjab Technical University, Jalandhar- 144603(Punjab), India \\ *E-mail: chughveenu1@gmail.com
}

\begin{abstract}
Macrocyclic complexes of $\mathrm{Cr}^{3+}, \mathrm{Fe}^{3+}$ and $\mathrm{Co}^{3+}$ with Hexane-1, 6-diamine and ninhydrin as chlorides and bromides were prepared, characterized and their antibacterial studies were carried out. For structural determination of the complexes, data obtained from spectral studies such as analyses of elements, infrared spectra, conductivity measurements, $\mathrm{C}^{13}$ Nuclear Magnetic Resonance, Electron Spin Resonance, electronic spectra, mass spectral has been used. Crystal Structure was determined by powder X-ray diffraction method. All of the trivalent metal complexes show five-coordinate square-pyramidal geometry. The antibacterial study of newly prepared macrocyclic complexes was mainly focused on Bacillus subtilis, Bacillus thermophilus; the gram-positive strains and Escherichia coli, Pseudomonas putida; the gram-negative strains. The method used was Disc Diffusion Assay technique using Agar media. Streptomycin and Chloramphenicol were used as a reference for comparison as they are highly effective, broad-spectrum antibiotic drugs used both in humans and animals. Some of the complexes show antibacterial properties.

Keywords- Hexane-1, 6-diamine, Metal Halide, 2, 2-Dihydroxyindane-1, 3-dione, Physico-chemical Techniques, Antibacterial Screening.
\end{abstract}

(C) RASĀYAN. All rights reserved

\section{INTRODUCTION}

Peeping into the history of macrocyclic complexes, they are the compounds with versatility in their application. We find their wide and effective use as a therapeutic agent. Most of them have been recognized as good diagnostic agents. Transition metal complexes find resourcefulness in their behaviour due to small ionic size, high nuclear charge and empty d-orbitals present in metal and locked stable macrocyclic chelated rings ${ }^{1,2,3}$. The host-guest behaviour of the macrocyclic complexes has been shown due to different sizes of the cavities present in them which cause macrocyclic effect and significant molecular recognition properties. Naturally occurring macrocyclic complexes such as Haemoglobin, Chlorophyll, Vitamin $\mathrm{B}_{12}$ and Pthalocyanine, play an ideal role in biological systems. Macrocyclic complexes are of significant importance in medicines such as Cisplatin, Carboplatin and Oxaliplatin which are metal-based drugs used for chemotherapy. Gadolium complexes are used in MRI ${ }^{4-8}$ (Magnetic Resonance Imaging). These features show a correlation between chemistry and biology.

To synthesize new effective antibacterial drugs, our present work involves the synthesis of a new family of trivalent metal-based macrocyclic complexes using 2, 2-Dihydroxyindane-1, 3-dione and Hexane-1, 6diamine. Out of the two methods of synthesis, the high yielding template method was preferred over low yielding non- template one. The characterization of synthesized macrocyclic complexes was done via spectroscopic techniques like UV-VIS, IR, ESR, MASS, ${ }^{13} \mathrm{C}$ NMR etc. The gram-positive strains of the bacteria Bacillus subtilius and Bacillus thermophilus were picked up for testing. The antibacterial activity was repeated for gram-negative bacteria, Escherichia coli and Pseudomonas putida.

Rasayan J. Chem., 13(3), 1926-1932(2020)

http://dx.doi.org/10.31788/ RJC.2020.1335629 
RASĀYAN J. Chem.

Vol. 13 | No. 3 |1926-1932| July - September | 2020

Material and Methods

\section{EXPERIMENTAL}

The chemicals used in the synthesis were purchased from the standard brands Merck, Fischer scientific and NICE chemicals. 2, 2-Dihydroxyindane-1, 3-dione(Ninhydrin) was purchased from Pierce Protein Research Products. Both the template and non-template methods of synthesis were tried and the template synthesis was preferred as the yields obtained were better in it.

\section{General Procedure}

The salt of trivalent chromium, iron, cobalt $(5 \mathrm{mmol})$ dissolved in the least amount quantity of methanol was mixed with a hot solution $\left(\sim 50 \mathrm{~cm}^{3}\right)$ of 2, 2-Dihydroxyindane-1, 3-dione (10mmol) made in methanol in a round bottom flask. This mixture was refluxed for half an hour. Later, Hexane-1, 6-diamine $(10 \mathrm{mmol})$ was added to the refluxing mixture and further refluxing was continued for $8-10 \mathrm{hrs}$. The mixture was reduced to half of its original volume. It was then stored in a desiccator for 2 days for precipitation of the complexes. The coloured crystals of the complexes were obtained which were found soluble only in Dimethylfornamide or Dimethylsulphoxide Table-4. The synthesized complexes were filtered and dried. TLC was used to check the purity of the complex obtained.

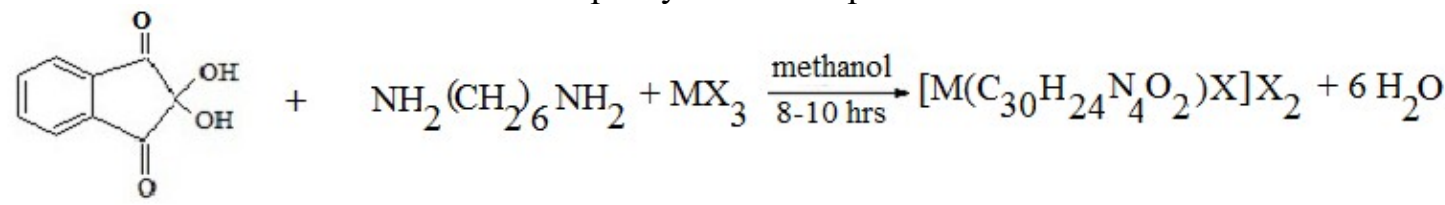

\section{2,2-dihydroxyindane-1,3-dione Hexane-1,6-diamine Macrocyclic complex}

Scheme-1

\section{RESULTS AND DISCUSSION}

Molar Conductance of the complexes was determined by Dip type Conductivity Bridge (HPG System, G3001) and it was found to be in the range $95-120 \mathrm{mho} \mathrm{cm}^{2} \mathrm{~mol}^{-1}$. These results suggest the number of cations and anions which are released in the solution through ionization. The molar conductance measurements in DMF indicated the ratio of cation to anion as $1: 2^{9}$. The analytical data obtained from SAIF, CFL, Panjab University, Chandigarh and molar conductance data suggest the formula of the complexes as $\left[\mathrm{M}\left(\mathrm{C}_{30} \mathrm{H}_{24} \mathrm{~N}_{4} \mathrm{O}_{2} \mathrm{X}\right)\right] \mathrm{X}_{2}$ Where $\mathrm{M}=\mathrm{Cr}^{3+}, \mathrm{Fe}^{3+}$ and $\mathrm{Co}^{3+}$ and $\mathrm{X}$ is either bromine or chlorine. Table- 1 and 2 represent the obtained analytical analysis.

Table-1: Elemental Analysis of $\mathrm{Cr}^{3+}, \mathrm{Fe}^{3+}$ and $\mathrm{Co}^{3+}$ Complexes obtained from Hexane-1, 6-diamine and 2,2Dihydroxyindane-1,3-dione

\begin{tabular}{c|c|c|c|c|c|c}
\hline \multirow{2}{*}{ S.No. } & \multirow{2}{*}{ Complexes } & \multicolumn{4}{|c|}{ Found (cal \%) } & \multirow{2}{*}{ Mol wt } \\
\cline { 3 - 6 } & & $\mathrm{M}$ & $\mathrm{C}$ & $\mathrm{H}$ & $\mathrm{N}$ & \\
\hline 1 & {$\left[\mathrm{Cr}\left(\mathrm{C}_{30} \mathrm{H}_{24} \mathrm{~N}_{4} \mathrm{O}_{2}\right) \mathrm{Cl}\right] \mathrm{Cl}_{2}$} & $09.20(9.23)$ & $61.5(63.8)$ & $4.0(4.25)$ & $9.85(9.90)$ & 563.5 \\
\hline 2 & {$\left[\mathrm{Cr}\left(\mathrm{C}_{30} \mathrm{H}_{24} \mathrm{~N}_{4} \mathrm{O}_{2}\right) \mathrm{Br}_{\mathrm{Br}_{2}}\right.$} & $08.49(8.55)$ & $58.0(59.2)$ & $3.92(3.95)$ & $8.2(8.55)$ & 608 \\
\hline 3 & {$\left[\mathrm{Fe}\left(\mathrm{C}_{30} \mathrm{H}_{24} \mathrm{~N}_{4} \mathrm{O}_{2}\right) \mathrm{Cl}\right] \mathrm{Cl}_{2}$} & $09.65(9.70)$ & $62.8(63.5)$ & $4.18(4.23)$ & $9.63(9.70)$ & 566.5 \\
\hline 4 & {$\left[\mathrm{Fe}\left(\mathrm{C}_{30} \mathrm{H}_{24} \mathrm{~N}_{4} \mathrm{O}_{2}\right) \mathrm{Br}\right] \mathrm{Br}_{2}$} & $08.38(9.00)$ & $55.0(58.9)$ & $3.80(3.93)$ & $8.96(9.00)$ & 611 \\
\hline 5 & {$\left[\mathrm{Co}\left(\mathrm{C}_{30} \mathrm{H}_{24} \mathrm{~N}_{4} \mathrm{O}_{2}\right) \mathrm{Cl}\right] \mathrm{Cl}_{2}$} & $10.44(10.54)$ & $63.7(64.3)$ & $4.10(4.29)$ & $10.52(10.54)$ & 559.5 \\
\hline 6 & {$\left[\mathrm{Co}\left(\mathrm{C}_{30} \mathrm{H}_{24} \mathrm{~N}_{4} \mathrm{O}_{2}\right) \mathrm{Br}_{3}\right] \mathrm{Br}_{2}$} & $09.60(9.76)$ & $58.3(59.6)$ & $3.82(3.97)$ & $9.64(9.76)$ & 604 \\
\hline
\end{tabular}

Table-2: Analytical Data of $\mathrm{Cr}^{3+}, \mathrm{Fe}^{3+}$ and $\mathrm{Co}^{3+}$ Complexes obtained from Hexane-1, 6-diamine and 2, 2Dihydroxyindane-1, 3-dione.

\begin{tabular}{c|c|c|c|c}
\hline S.No. & Complexes & Colour & Molar Conductance & Yield \\
\hline 1 & {$\left[\mathrm{Cr}\left(\mathrm{C}_{30} \mathrm{H}_{24} \mathrm{~N}_{4} \mathrm{O}_{2}\right) \mathrm{Cl}_{\mathrm{Cl}}\right.$} & Shinny Green Powder & 103 & 53 \\
\hline 2 & {$\left[\mathrm{Cr}\left(\mathrm{C}_{30} \mathrm{H}_{24} \mathrm{~N}_{4} \mathrm{O}_{2}\right) \mathrm{Br}\right] \mathrm{Br}_{2}$} & Blackish Powder & 110 & 59 \\
\hline 3 & {$\left[\mathrm{Fe}\left(\mathrm{C}_{30} \mathrm{H}_{24} \mathrm{~N}_{4} \mathrm{O}_{2}\right) \mathrm{Cl}\right] \mathrm{Cl}_{2}$} & Shinny Black & 101 & 41 \\
\hline 4 & {$\left[\mathrm{Fe}\left(\mathrm{C}_{30} \mathrm{H}_{24} \mathrm{~N}_{4} \mathrm{O}_{2}\right){\mathrm{Br}] \mathrm{Br}_{2}}\right.$} & Black Powder & 112 & 46 \\
\hline 5 & {$\left[\mathrm{Co}\left(\mathrm{C}_{30} \mathrm{H}_{24} \mathrm{~N}_{4} \mathrm{O}_{2}\right) \mathrm{Cl}\right] \mathrm{Cl}_{2}$} & Shinny Grey Powder & 99 & 53 \\
\hline 6 & {$\left[\mathrm{Co}\left(\mathrm{C}_{30} \mathrm{H}_{24} \mathrm{~N}_{4} \mathrm{O}_{2}\right) \mathrm{Br}_{\mathrm{Br}_{2}}\right.$} & Blackish Powder & 108 & 43 \\
\hline
\end{tabular}

1927 
RASĀYAN J. Chem.

Vol. 13 | No. 3 |1926-1932| July - September | 2020

\section{IR Spectra}

The complexes and the ligands were subjected to infrared radiations IR spectra to obtain the spectrum on FT-IR/FT-FIR spectrophotometer (Perkin Elmer Spectrum 400); range 4000-667 $\mathrm{cm}^{-1}$ using $\mathrm{KBr}$ pellets at SAIF, CFL, Panjab University, Chandigarh and plots were obtained between \%transmittance and wave number. A strong band appeared at $1716-1780 \mathrm{~cm}^{-1}$ in all complexes. This has appeared due to the presence of carbonyl $>\mathrm{C}=\mathrm{O}$ group. The geminal hydroxyl groups of ninhydrin (2, 2-Dihydroxyindane-1, 3-dione) undergo dehydration on heating to produce carbonyl in all the metal complexes. A strong band was seen at $\sim 1405-1689 \mathrm{~cm}^{-1}$ indicating $>\mathrm{C}=\mathrm{N}$ - stretching vibrations but this band position was not found in IR spectra of Hexane-1, 6-diamine and 2, 2-Dihydroxyindane-1, 3-dione from which these complexes were synthesized. This indicates the attachment of the carbonyl of dione with amino group of the diamine. The low value of $->\mathrm{C}=\mathrm{N}$ - stretching frequency gives an idea about the formation of macrocyclic frame and migration of lone pair present on nitrogen towards metal atom for coordination ${ }^{10-11}$. The various peaks for all macrocyclic complexes were given as in Table-3.

Table-3: IR Spectra of All Metal Complexes

\begin{tabular}{c|c|c|c|c}
\hline S. No. & Complexes & $v(\mathrm{C}=\mathrm{N}) \mathrm{cm}^{-1}$ & $v(\mathrm{C}=\mathrm{O}) \mathrm{cm}^{-1}$ & $v(\mathrm{M}-\mathrm{N}) \mathrm{cm}^{-1}$ \\
\hline 1. & {$\left[\mathrm{Fe}\left(\mathrm{C}_{30} \mathrm{H}_{24} \mathrm{~N}_{4} \mathrm{O}_{2}\right) \mathrm{Cl}\right] \mathrm{Cl}_{2}$} & 1679 & 1757 & 500 \\
\hline 2. & {$\left[\mathrm{Fe}\left(\mathrm{C}_{30} \mathrm{H}_{24} \mathrm{~N}_{4} \mathrm{O}_{2}\right) \mathrm{Br}_{\mathrm{Br}_{2}}\right.$} & 1689 & 1780 & 484 \\
\hline 3. & {$\left[\mathrm{Co}\left(\mathrm{C}_{30} \mathrm{H}_{24} \mathrm{~N}_{4} \mathrm{O}_{2}\right) \mathrm{Cl}\right] \mathrm{Cl}_{2}$} & 1463 & 1716 & 439 \\
\hline 4. & {$\left[\mathrm{Co}\left(\mathrm{C}_{30} \mathrm{H}_{24} \mathrm{~N}_{4} \mathrm{O}_{2}\right) \mathrm{Br}_{\mathrm{Br}_{2}}\right.$} & 1405 & 1752 & 527 \\
\hline 5. & {$\left[\mathrm{Cr}\left(\mathrm{C}_{30} \mathrm{H}_{24} \mathrm{~N}_{4} \mathrm{O}_{2}\right) \mathrm{Cl}\right] \mathrm{Cl}_{2}$} & 1636 & 1763 & 497 \\
\hline 6. & {$\left[\mathrm{Cr}\left(\mathrm{C}_{30} \mathrm{H}_{24} \mathrm{~N}_{4} \mathrm{O}_{2}\right) \mathrm{Br}_{\mathrm{Br}_{2}}\right.$} & 1586 & 1720 & 415 \\
\hline
\end{tabular}

Solubility was checked in the following solvents and the data collected as given in Table-4.

Table-4

\begin{tabular}{c|c|c}
\hline S. No. & Solvent & Solubility \\
\hline 1. & Diethyl Ether & Not Soluble \\
\hline 2. & Methanol & Not Soluble \\
\hline 3. & Ethanol & Not Soluble \\
\hline 4. & Ethyl Acetate & Not Soluble \\
\hline 5. & Acetone & Not Soluble \\
\hline 6. & Benzene & Not Soluble \\
\hline 7. & Dimethyl Formamide & Soluble \\
\hline 8. & Dimethyl Sulphoxide & Soluble \\
\hline
\end{tabular}

\section{${ }^{1}$ H NMR Spectra}

The ${ }^{1} \mathrm{HMR}$ spectra could not be obtained due to the insolubility of the complexes in general organic solvents. A clear solution could not be obtained.

\section{Electronic Spectra and Magnetic Moment}

Electronic spectra are very useful for the revelation of the geometry of the macrocyclic complexes which arise due to the absorption of radiation leading to d-d electronic transitions. The d-orbitals in transition metals are split into different energy levels. This split is due to the repulsions between the $e_{g}$ and $t_{2 g}$ orbitals of transition metal and the electron cloud of the ligand. Hence electrons from lower energy levels are transited into a higher energy level with the absorption of energy from the UV-Vis region. The electronic transition takes only $10-15 \mathrm{sec}$ due to which the atoms in the molecules remain in their positions. Hence, the molecular configuration remains unchanged. There is no change in vibrational K.E in the excited state concerning the ground state at the moment of absorption. The transitions occur from $v_{0}$ to $v_{1}, v_{2}, v_{3} \ldots . v_{n}$. The different term symbols are used for exciting vibrational levels as ${ }^{4} \mathrm{~B}_{1},{ }^{4} \mathrm{E}_{\mathrm{a}},{ }^{4} \mathrm{~A}_{2}$.

$\mathrm{Cr}^{3+}$ complexes: $\mathrm{Cr}^{3+}$ macrocyclic complexes show a magnetic moment at $\sim 4.0-4.2$ B.M. The electronic spectra of $\mathrm{Cr}^{3+}$ show three bands at $9900 \mathrm{~cm}^{-1}, 15000 \mathrm{~cm}^{-1}$ and $21000 \mathrm{~cm}^{-1}$. These spectra resemble with spectra of the square pyramidal. With the confirmation of the literature data, five coordinated square pyramidal geometry has been suggested. Thus, considering $\mathrm{C}_{4 \mathrm{~V}}$ for these complexes, the spectral bands may be assigned as ${ }^{4} \mathrm{~B}_{1} \rightarrow{ }^{4} \mathrm{E}_{\mathrm{a}},{ }^{4} \mathrm{~B}_{1} \rightarrow{ }^{4} \mathrm{~B}_{2},{ }^{4} \mathrm{~B}_{1} \rightarrow{ }^{4} \mathrm{~A}_{2}$, and ${ }^{4} \mathrm{~B}_{1} \rightarrow{ }^{4} \mathrm{E}_{\mathrm{b}} \cdot{ }^{12-15}$ 
RASĀYAN J. Chem.

Vol. 13 | No. 3 |1926-1932| July - September | 2020

$\mathrm{Fe}^{3+}$ complexes: $\mathrm{Fe}^{3+}$ complexes show the magnetic moment at $\sim 5.25-5.65 \mathrm{~B} . \mathrm{M}$ confirming the presence of five unpaired electrons ${ }^{12,13}$. The spectra data indicates the three bands at $9500 \mathrm{~cm}^{-1}, 16500 \mathrm{~cm}^{-1}$ and $28000 \mathrm{~cm}^{-1}$. The analytical data reports the bands as $\mathrm{d}_{\mathrm{xy}} \rightarrow \mathrm{d}_{\mathrm{xz},} \mathrm{d}_{\mathrm{yz}}, \mathrm{d}_{\mathrm{xy}} \rightarrow \mathrm{dz}^{2}$.

$\mathrm{Co}^{3+}$ complexes: $\mathrm{Co}^{3+}$ complexes show magnetic moment at 5.95 B.M. This value of magnetic moment indicates the presence of not more than four unpaired electrons in $\mathrm{Co}^{3+}$. The electronic configuration was to be $3 \mathrm{~d}^{6} 4 \mathrm{~s}^{0}$. It has four unpaired electrons. The bands are shown in the spectra as $18000 \mathrm{~cm}^{-1}, 25000 \mathrm{~cm}^{-1}$ and $35000 \mathrm{~cm}^{-1}$.

\section{${ }^{13}$ C NMR Spectra}

${ }^{13} \mathrm{C}$ NMR spectra were collected from Bruker Avance Neo II 500 NMR spectrophotometer using DMSO as a solvent and TMS as reference. The ${ }^{13} \mathrm{C}$ NMR spectra of all macrocyclic complexes were compared with spectra of Hexane-1, 6-diamine and 2, 2-Dihydroxyindane-1, 3-dione in terms of chemical shifts (ppm). A upward or shielding shift was observed at $\sim 40.32 \mathrm{ppm}$ which indicates the contribution of the electrons from the ligand towards metal atom. No change was to be found in the peaks of aryl carbon and any other carbon linked to donor atom. ${ }^{14}$

\section{Mass Spectra}

The mass spectrum of all the metal complexes, were reported on mass spectrometer at SAIF, CFL, Panjab University, Chandigarh using LC-MS Spectrometer Model Q-ToF Micro Waters. Mass spectra give various peaks that were assigned to different fragments and molecules. It gives molecular ion peaks at different values that correspond to $[\mathrm{M}]^{+}$. The peaks $[\mathrm{M}]^{+}$and $[\mathrm{M}+4]^{+}$values indicate the coordination of one halogen $(\mathrm{Cl} / \mathrm{Br})$ inside the sphere and two halogens outside the coordination sphere representing primary valency and secondary valency successively.

$\left[\mathrm{Fe}\left(\mathrm{C}_{30} \mathrm{H}_{24} \mathrm{~N}_{4} \mathrm{O}_{2}\right) \mathrm{Cl}\right]^{+}=563.5$ and 565.5, $\left[\mathrm{Fe}\left(\mathrm{C}_{30} \mathrm{H}_{24} \mathrm{~N}_{4} \mathrm{O}_{2}\right) \mathrm{Br}\right]^{+}=608$ and $610,\left[\mathrm{Co}\left(\mathrm{C}_{30} \mathrm{H}_{24} \mathrm{~N}_{4} \mathrm{O}_{2}\right) \mathrm{Cl}\right]^{+}=566.5$ and $568\left[\mathrm{Co}\left(\mathrm{C}_{30} \mathrm{H}_{24} \mathrm{~N}_{4} \mathrm{O}_{2}\right) \mathrm{Br}\right]^{+}=611$ and 613, $\left[\mathrm{Cr}\left(\mathrm{C}_{30} \mathrm{H}_{24} \mathrm{~N}_{4} \mathrm{O}_{2}\right) \mathrm{Cl}\right]^{+}=559.5$ and 561.5, $\left[\mathrm{Cr}\left(\mathrm{C}_{30} \mathrm{H}_{24} \mathrm{~N}_{4} \mathrm{O}_{2}\right) \mathrm{Br}\right]^{+}=604$ and 606 .

\section{Powder Method}

Powder method is the technical method used for the detection of the crystal structure of the sample. They were obtained from SAIF, CFL, Panjab University, Chandigarh using XPERT-PRO PAN analytical with $\mathrm{Cu}$ as X-ray source and scanning range $\left(0-80^{\circ} \mathrm{C}\right)$. Discs were used for the scanning of the powder samples. To keep away from moisture, special sample tubes were used. The samples of trivalent metal ions disclose amorphous nature due to broadening peaks. The unit cell of $\mathrm{Cr}^{3+}$ gives $\mathrm{a}=4.9588$ $\mathrm{A}^{0}, \mathrm{~b}=4.9588 \mathrm{~A}^{0}$ and $\mathrm{c}=13.5942 \mathrm{~A}^{0}, \alpha=90.0000, \beta=90.0000$ and $\gamma=120.0000$, density $=5.23 \mathrm{~g} / \mathrm{cm} 3$, the unit cell of $\mathrm{Fe}^{3+}$ gives $\mathrm{a}=4.9890 \mathrm{~A}^{0}, \mathrm{~b}=4.9890 \mathrm{~A}^{0}$ and $\mathrm{c}=17.0620 \mathrm{~A}^{0}, \alpha=90.0000, \beta=90.0000$ and $\gamma=120.0000$, density $=2.71 \mathrm{~g} / \mathrm{cm} 3$ and $\mathrm{Co}^{3+}$ gives $\mathrm{a}=6.7766 \mathrm{~A}^{0}, \mathrm{~b}=6.7788 \mathrm{~A}^{0}$ and $\mathrm{c}=9.8978 \mathrm{~A}^{0}$ and $\alpha=90.0000, \beta=90.0000$ and $\gamma=120.0000$ which indicates rhombohedral structure for $\mathrm{Cr}^{3+}$ and $\mathrm{Fe}^{3+}$ complexes and monoclinic system for $\mathrm{Co}^{3+}$ complexes ${ }^{17}$. The diffractograms depicting $2 \theta$ values and relative intensity using Origin 8 software were shown as ${ }^{18}$ (Fig-1).

\section{Antibacterial Assay of Trivalent Cobalt, Iron and Chromium Complexes Derived From Hexane-1, 6-diamine and 2, 2-Dihydroxyindane-1, 3-Dione}

The bacterial gram-positive strains; Bacillus subtilis (MTCC 8509) and Bacillus stearothermophilus (MTCC 8508), The bacterial gram-negative strains; Escherichia coli (MTCC 51) and Pseudomonas putida (MTCC 121) were was purchased from culture collection and gene bank, Institute of Microbial Technology, Chandigarh, India. These bacterial samples were used for antibacterial study of the synthesized complexes. ${ }^{19-20}$

\section{Antibacterial Technique}

Hole Diffusion technique was used to ascertain the antibacterial behaviour of newly synthesized complexes. Both Gram-positive bacteria and Gram-negative bacteria were tested by the same Hole Diffusion technique. ${ }^{21-23}$ A laminar airflow chamber was also used. $20 \mathrm{ml}$ of MHA (Mueller- HintonAgar) medium was dispersed into pre-sterilized petridishes, under aseptic conditions. The solidified medium was inoculated with microorganism suspended in peptone water. Holes of $6 \mathrm{~mm}$ diameter were 
RASĀYAN J. Chem.

Vol. 13 | No. 3 |1926-1932 | July - September | 2020

punched in the media with the help of cork and these were filled with different solutions of different concentrations (ppm) using DMSO as a solvent. They were mentioned as a, b, c, d. Streptomycin and Chlorampenicol antibiotics were used as standard antibiotics and DMSO used a test control. At the last, the petridishes were stored in an incubator at $37^{\circ} \mathrm{Cfor} 24$ hours. The diameter of circumference developed around the hole was measured the next day. The experiment was repeated thrice for determining MIC (minimum inhibitory concentration). The MIC was determined by subtracting the value of circumference of the solvent from the circumference of macrocyclic complexes.
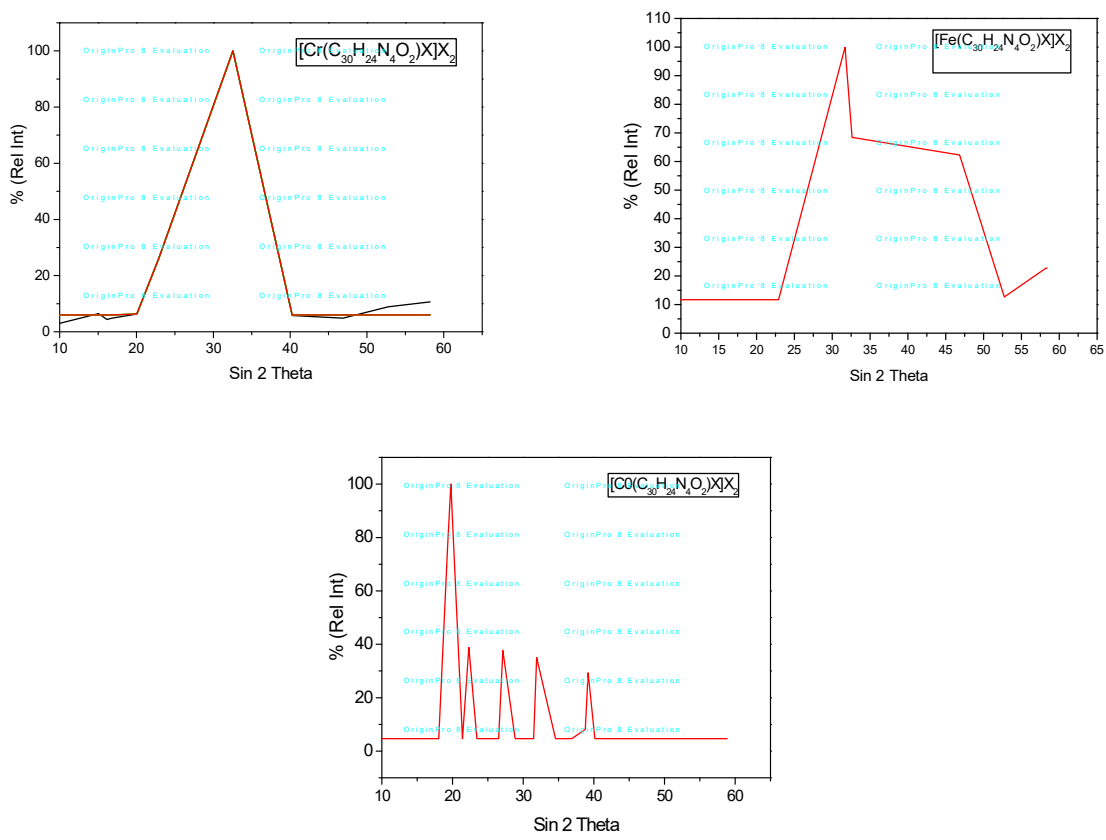

Fig.-1

Antibacterial activities of trivalent Chromium, Iron and Cobalt complexes derived from Hexane-1, 6diamine and 2, 2-Dihydroxyindane-1, 3-Dione. The comparison of MIC values of Gram-positive bacteria and Gram-negative bacteria with standard antibiotics (Chlorampenicol and Streptomycin) were listed in Table-5.

Table-5: Minimum Inhibitory Concentration (MIC) of Trivalent Metal Complexes Obtained from 2, 2-

Dihydroxyindane-1, 3-dione and Hexane-1, 6-diamine against Test Bacteria by Using Hole Diffusion Technique

\begin{tabular}{|c|c|c|c|c|c|}
\hline \multirow{2}{*}{ S. No. } & \multirow{2}{*}{ Complexes } & \multicolumn{4}{|c|}{ MIC } \\
\hline & & A & $\mathrm{B}$ & $\mathrm{C}$ & $\mathrm{D}$ \\
\hline 1 & {$\left[\mathrm{Cr}\left(\mathrm{C}_{30} \mathrm{H}_{24} \mathrm{~N}_{4} \mathrm{O}_{2}\right) \mathrm{Cl}\right] \mathrm{Cl}_{2}$} & $>16$ & $>16$ & 32 & 32 \\
\hline 2 & {$\left[\mathrm{Cr}\left(\mathrm{C}_{30} \mathrm{H}_{24} \mathrm{~N}_{4} \mathrm{O}_{2}\right) \mathrm{Br}\right] \mathrm{Br}_{2}$} & 32 & 32 & $>64$ & 32 \\
\hline 3 & {$\left[\mathrm{Fe}\left(\mathrm{C}_{30} \mathrm{H}_{24} \mathrm{~N}_{4} \mathrm{O}_{2}\right) \mathrm{Cl}\right] \mathrm{Cl}_{2}$} & 08 & 02 & 02 & 08 \\
\hline 4 & {$\left[\mathrm{Fe}\left(\mathrm{C}_{30} \mathrm{H}_{24} \mathrm{~N}_{4} \mathrm{O}_{2}\right) \mathrm{Br}\right] \mathrm{Br}_{2}$} & 02 & 02 & 04 & 04 \\
\hline 5 & {$\left[\mathrm{Co}\left(\mathrm{C}_{30} \mathrm{H}_{24} \mathrm{~N}_{4} \mathrm{O}_{2}\right) \mathrm{Cl}\right] \mathrm{Cl}_{2}$} & $>64$ & 32 & 32 & 32 \\
\hline 6 & {$\left[\mathrm{Co}\left(\mathrm{C}_{30} \mathrm{H}_{24} \mathrm{~N}_{4} \mathrm{O}_{2}\right) \mathrm{Br}\right] \mathrm{Br}_{2}$} & 32 & $>32$ & 32 & 16 \\
\hline 7 & Chlorampenicol & 02 & 02 & 06 & 08 \\
\hline 8 & Streptomycin & 02 & 02 & 04 & 04 \\
\hline
\end{tabular}

Where,
A - Bacillus subtilis (MTCC 8509)
B - Bacillus stearothermophilus (MTCC 8508)
C- Pseudomonas putida (MTCC 121)
D- Escherichia coli (MTCC 51)

\section{Chloramphenicol, Streptomycin-Standard Antibiotics}

The comparison of MIC values of Gram-positive bacteria and Gram-negative bacteria with standard antibiotics were shown in the bar graph (Fig-2): 
RASĀYAN J. Chem.

Vol. 13 | No. 3 |1926-1932 | July - September | 2020

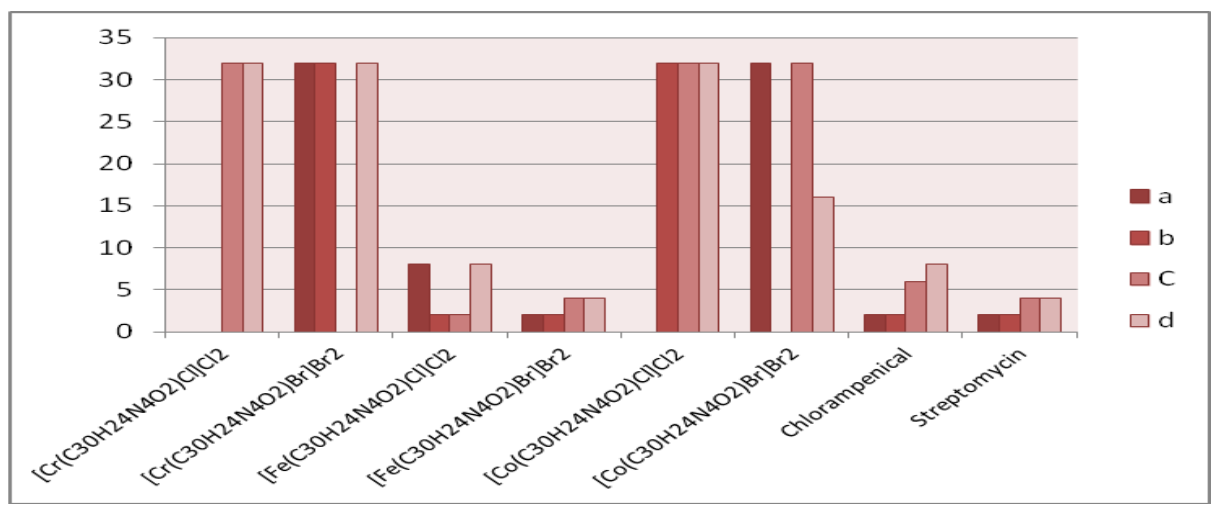

Fig.-2

\section{Proposed Structure}

Various analytical and spectral methods like elemental analyses, magnetic susceptibilities, conductance measurements, NMR, UV-Vis, infrared, XRD Spectra suggests a square pyramidal geometry for all the trivalent macrocyclic metal complexes as shown in Fig.-3 may be proposed.

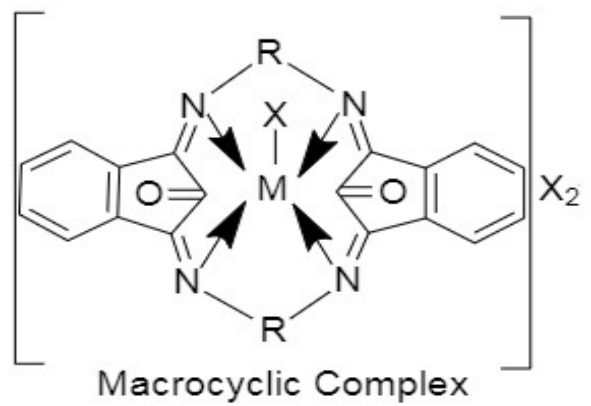

Where, $\mathrm{R}=\left(-\mathrm{CH}_{2}\right)_{6^{-}}, \mathrm{X}=\mathrm{Cl}^{-} / \mathrm{Br}^{-}, \mathrm{M}=\mathrm{Cr}^{3+}, \mathrm{Fe}^{3+}, \mathrm{Co}^{3+}$

Fig.-3

\section{CONCLUSION}

Based on the preparation, characterization and structural elucidation data it is proposed that the Template synthesis is a better yielding method of preparation. The cyclization and coordination are taking place simultaneously in template synthesis. Trivalent metal complexes of Chromium, Iron and Cobalt are square-pyramidal in geometry. They are ionic of the ratio 1:2 of cation to anion in DMSO and DMF. Iron complex as bromide are found to be effective antibacterial towards both gram-positive and gram-negative bacteria. These compounds can be used for further pharmaceutical studies.

\section{ACKNOWLEDGEMENT}

The authors are grateful to Director, Shaheed Bhagat Singh State Technical Campus, Ferozepur, IK Gujral Punjab Technical University, Kapurthala and Director (SAIF) Punjab University, Chandigarh for offering the necessary specialized help for investigation.

\section{REFERENCES}

1. Z.H. Chohan, H. Pervez, A. Rauf, K.M. Khan, C.T. Supuran, Journal of Enzyme Inhibition and Medicinal Chemistry, 19, 417(2004), DOI:10.1080/14756360410001710383

2. S. Fortuna, F. Fogolari, G. Scoles, Scientific Reports, 5, 15633(2015), DOI:10.1038/srep15633

3. D.J.Cram, Angewandte Chemie International Edition in English, 27, 1009(1988), DOI: 10.1002/anie.198810093

4. M. D. Sousa. Healy, A.J. Rest, Advances in Inorganic Chemistry and Radiochemistry, 21, 1(1978), DOI:10.1016/S0065-2792(08) 60277-0

5. L.F. Lindoy, The chemistry of macrocyclic ligand complexes, Cambridge University Press, New York (1989), DOI:10.1002/ange.1989101125 
RASĀYAN J. Chem.

Vol. 13 | No. 3 |1926-1932| July - September | 2020

6. O.D. Fox, M.G.B, Drew, E.J.S. Wilkinson, O.P. Beer, Chemical Communications, 5, 319(2000)

7. M.T.H. Tarafdar, N. Saravanan, K.A. Crouse, Transition Metal Chemistry, 26, 613(2001), DOI: $10.1023 / \mathrm{A}: 1012047001167$

8. M.A. Ali, C. M. Haroon, M. Nazimudin, S.M.M. Majumdar, M.T.H. Tarafdar, M.A. Khair, Transition Metal Chemistry, 17, 133(1992), DOI:10.1023/A:1013434113299

9. D.P. Singh, N. Shishodia, B.P. Yadav and V.B. Rana, Journal of Indian Chemical Society, 81, 287(2004).

10. W.J.Geary, Coordination Chemistry Reviews, 7, 81(1971), DOI:10.1016/S0010-8545(00)80009-0

11. S. Chandra, R. Gupta, N. Gupta, S. S. Bawa, Transition Metal Chemistry, 31, 147(2006), DOI: $10.1007 / \mathrm{s} 11243-005-6194-5$

12. L.K. Gupta, S. Chandra, Transition Metal Chemistry, 31, 368(2006), DOI:10.1007/s11243-005-00020

13. S.Chandra, K. Gupta, Transition Metal Chemistry, 27, 196(2002), DOI:10.1023/A:1013935602736

14. M.Pervaiz, M.Yousaf, M.Sagir, A. Pervaiz, and Yasin Naz, M., Trends in Applied Research, 9 (3), 132(2014), DOI:10.3923/tasr.2014.132.143

15. B. N. Figgis, The Magnetic Properties of the Complex Ions. Introduction to ligand fields, Ist Ed., Wiley Interscience, New York., 272-281 (1996)

16. Rimpi Mehani née Chopra, Rasayan Journal of Chemistry, 11, 694(2018), DOI: $10.31788 /$ RJC.2018.1121953

17. Enaam I. Yousif, Hasan A. Hasan, Riyadh M. Ahmed and Mohamad J. Al-JebooriJ.M. Al-Jeboori, Der Chemica Sinica, 7, 53(2016)

18. P. Rathi, D.P. Singh and P. Surain, Comptes Rendus Chimie, 18, 430(2015), DOI: $10.1016 /$ j.crci.2014.08.002

19. D.D. Suryawanshi, S.T. Gaikwad and A.S. Rajbhoj, Chemical Science Transactions, 3(1), 117(2014), DOI: $10.7598 /$ cst2014.646

20. K.C. Bhattacharya, An Elementary Physics for Indian School, the Indian Press Ltd. Allahabad, 105(1935)

21. S. H. Sakr, H.S. Elshafie, I. Camele and S.A. Sadeek, Molecules, 23, 1182(2018), DOI: 10.3390/molecules 23051182

22. D.P. Singh, V. Grover, P. Rathi and K.Jain, Arabian Journal of Chemistry, 10, S1795(2017), DOI: $10.1016 /$ j.arabjc.2013.07.004

23. Y. Satyawana, R. Meena, R.V. Singh and N. Fahmi, Rasayan Journal of Chemistry, 12(4), 2328(2019), DOI: 10.31788/RJC.2019.1245459

[RJC-5629/2020] 